\title{
Rasch Model on Serang City's Food Security Instrument Based on Milkfish's Stability and Availibility
}

\author{
*Benny Irawan \\ University of Sultan Ageng Tirtayasa, \\ Indonesia Center of Execelenc for \\ Food Security (I-CEFORY), \\ UNTIRTA (Local Food \\ Innovation) \\ Banten, Indonesia \\ *benny.irawan@untirta.ac.id
}

\author{
Nurul Anriani \\ University of Sultan Ageng Tirtayasa, \\ Indonesia Center of Execelenc for \\ Food Security (I-CEFORY), \\ UNTIRTA (Local Food \\ Innovation) \\ Banten, Indonesia \\ nurul_anriani@untirta.ac.id
}

\author{
Ahsanul Khair Asdar \\ STABN Sriwijaya \\ Tanggerang Banten, Indonesia \\ ahsanul.khair@stabn-sriwijaya.ac.id
}

\begin{abstract}
This study was a development research which aimed to develop the food security instrument then described the Serang City's food security based on milkfish's stability and availability. The respondents in this study were 215 persons which selected by using cluster random sampling. The data were analyzed by using Rasch Model approach and descriptive statistics. The results showed that food security was composed of four indicators namely milkfish's productivity, milkfish's availability, consumption sufficiency, and milkfish's shortcoming solution. The food security instrument was consisted of 24 questions with reliability coefficient was 0,99 .
\end{abstract}

Keywords: Food Security, Rasch Model, Stability, Availability, Milkfish, Development

\section{INTRODUCTION}

Food is a basic need that must be available at all times, both in terms of quantity and quality, safety, nutrition, and accessibility by people's purchasing power. The food's shortcoming was not only have an economic impact, but also threaten the social security. As the main objective of the Millennium Development Goals (MDGs) is to tackle extreme poverty and hunger, so that by 2015 the poverty rate and hunger rate will be reduced to half of the level that existed when the agreement was signed in September 2000 [1]. The successful in strengthening food security and reducing the number of poor people is a big challenge for the government and the community in implementing the national development.

Food security is a condition for the fulfillment of food for individuals and households which is reflected in the availability of sufficient food, both in quantity and quality, safety, equty, and accessibility. The concept of food security is in line with the definition of food security according to the Food and Agriculture Organization (FAO) and the World Health Organization (WHO), namely access for every household and individual to be able to obtain food at any time for the needs of a healthy life [2].

The results of the 2009 and 2015 FSVA, there are three main problems affecting the national food security, including low economic access to food, many cases of malnutrition and vigilance in dealing with climate change [3]. The current food system is influenced by the internal and external factors that can change quickly into vulnerable conditions [4]. Things that are slow but have major impacts such as climate change, land degradation, pest attacks, economic and political crises and population growth, are increasingly adding pressure on the global food system. Achieving food security in any country is usually a guarantee against hunger and malnutrition, both of which can slow economic development [5].

In the perspective of the food economy system, the food security has three main pillars, namely food availability, food accessibility, and food utilization. The pillar of food availability serves to guarantee food supply to meet the needs of the entire population, both in terms of quantity, quality, diversity, and safety. The distribution pillar functions to create an effective and efficient distribution system to ensure that all households can get adequate quantity and quality of food all the time at an affordable price. Meanwhile, the pillar of utilization serves to direct national food use patterns to meet the rules of quality, diversity, nutritional content, safety and halal status.

States that in addition to the three dimensions above, there is one more dimension of food security, namely stability [6]. However, stability here is a temporary factor of food security and its nature affects the other three dimensions. The stability of the three dimensions above determines the strength of food security. If one of these dimensions is not met, then a country cannot be said to have good food security. Even though food is sufficient at the national and regional levels, if individual access to meet their food needs is uneven, then food security is still said to be fragile. Likewise, although the availability and accessibility of the community can be said to be sufficient, but if food price stability is not able to be maintained properly and certainly results in availability and accessibility, then food security cannot be said to have been strong enough.

According to Arifin [7], food security is a challenge that gets priority to achieve the welfare of the nation in this century. Food needs in the world are increasing along with the increasing population in the world. The increase in population is not only the only problem that is hindering national food security. 
Likewise, Serang City which is famous as one of the biggest milkfish producing regions in Indonesia is one of the factors supporting food security in Serang City. Of course, the stability and availability of milkfish in Serang City will affect the food security in Serang City. The problem encountered is that the public perception about food security in Serang City is not yet known due to the unavailability of instruments that can measure it. In addition, a description has not yet been obtained regarding the stability and availability of milkfish in Serang City. So the purpose of this research is to develop the food security instrument and describe the stability and availability of milkfish in Serang City.

\section{METHOD}

This research was a development study which the data collection was carried out through a survey method to 215 respondents. The respondents were determined using cluster random sampling in the Serang City area. The instrument used to collect the data was the food security instrument in Serang City based on the stability and availability of milkfish. All research data were analyzed using the Rasch Model approach, followed by descriptive statistical analysis to see the stability and availability of milkfish in Serang City. The criteria used to declare an item fit according to [8] are as follows:

- Outfit Mean Square (MNSQ) which received was $0,5<\mathrm{MNSQ}<1,5$

- Outfit Z-standard (ZSTD) which received was -2,0 < ZSTD $<+2,0$

- $\quad$ Point Measure Correlation which received was 0,4 < $\mathrm{PMC}<0,85$

While the empirical criteria for the internal consistency reliability coefficient used in this study are $\rho_{\text {reliability }} \geq 0,70$ [5].

\section{A. Maintaining the Integrity of the Specifications}

The template is used to format your paper and style the text. All margins, column widths, line spaces, and text fonts are prescribed; please do not alter them. You may note peculiarities. For example, the head margin in this template measures proportionately more than is customary. This measurement and others are deliberate, using specifications that anticipate your paper as one part of the entire proceedings, and not as an independent document. Please do not revise any of the current designations.

\section{RESULT}

Based on the results of the analysis of research data using the Rasch Model approach obtained information that there are still several questions that are not fit. Nevertheless these points are still maintained by making improvements to the presentation of question items. This is because all items developed in content validity have been fulfilled. What needs to be done is to increase the number of research respondents. Based on these results obtained various possible biases that occur in respondents when filling research instruments. So that with improvements to the questions contained in the instrument, the whole item is still used.
The results of the analysis of the instrument items using the Rasch Model are presented in the following table I.

TABLE I. THE RESUlTS OF THE ANALYSIS OF INSTRUMENT ITEMS USING THE RASCH MODEL APPROACH

\begin{tabular}{|r|c|c|c|c|c|c|}
\hline \multirow{2}{*}{ Item } & \multicolumn{2}{|c|}{ MNSQ } & \multicolumn{2}{c|}{ ZSTD } & \multicolumn{2}{c|}{ PMC } \\
\cline { 2 - 7 } & Value & Decision & Value & Decision & Value & Decision \\
\hline 1 & 1,57 & Fit & 1,70 & Fit & 0,13 & Unfit \\
\hline 2 & 1,42 & Fit & 1,80 & Fit & 0,10 & Unfit \\
\hline 3 & 0,79 & Fit & $-1,90$ & Fit & 0,47 & Fit \\
\hline 4 & 0,79 & Fit & $-1,90$ & Fit & 0,47 & Fit \\
\hline 5 & 0,81 & Fit & $-0,70$ & Fit & 0,27 & Unfit \\
\hline 6 & 1,19 & Fit & 0,80 & Fit & 0,17 & Unfit \\
\hline 7 & 0,81 & Fit & $-0,70$ & Fit & 0,27 & Unfit \\
\hline 8 & 1,01 & Fit & 0,20 & Fit & 0,14 & Unfit \\
\hline 9 & 1,02 & Fit & 0,20 & Fit & 0,16 & Unfit \\
\hline 10 & 0,67 & Fit & $-0,90$ & Fit & 0,24 & Unfit \\
\hline 11 & 1,28 & Fit & 0,80 & Fit & 0,03 & Unfit \\
\hline 12 & 0,86 & Fit & $-0,20$ & Fit & 0,17 & Unfit \\
\hline 13 & 0,61 & Fit & $-0,70$ & Fit & 0,20 & Unfit \\
\hline 14 & 0,00 & Unfit & $-2,60$ & Unfit & 0,00 & Unfit \\
\hline 15 & 0,00 & Unfit & $-2,60$ & Unfit & 0,00 & Unfit \\
\hline 16 & 0,00 & Unfit & $-2,60$ & Unfit & 0,00 & Unfit \\
\hline 17 & 0,00 & Unfit & $-2,60$ & Unfit & 0,00 & Unfit \\
\hline 18 & 0,00 & Unfit & $-2,60$ & Unfit & 0,00 & Unfit \\
\hline 19 & 0,00 & Unfit & $-2,60$ & Unfit & 0,00 & Unfit \\
\hline 20 & 1,63 & Unfit & 4,40 & Unfit & 0,60 & Unfit \\
\hline 21 & 0,16 & Unfit & $-9,80$ & Unfit & 0,00 & Unfit \\
\hline 22 & 0,90 & Fit & $-1,10$ & Fit & 0,27 & Unfit \\
\hline 23 & 0,88 & Fit & $-1,50$ & Fit & 0,37 & Unfit \\
\hline 24 & 1,17 & Fit & 2,10 & Unfit & 0,17 & Unfit \\
\hline
\end{tabular}

While the visualization of 24 questions contained in the food security instrument using the Rasch Model approach, is presented as follows.

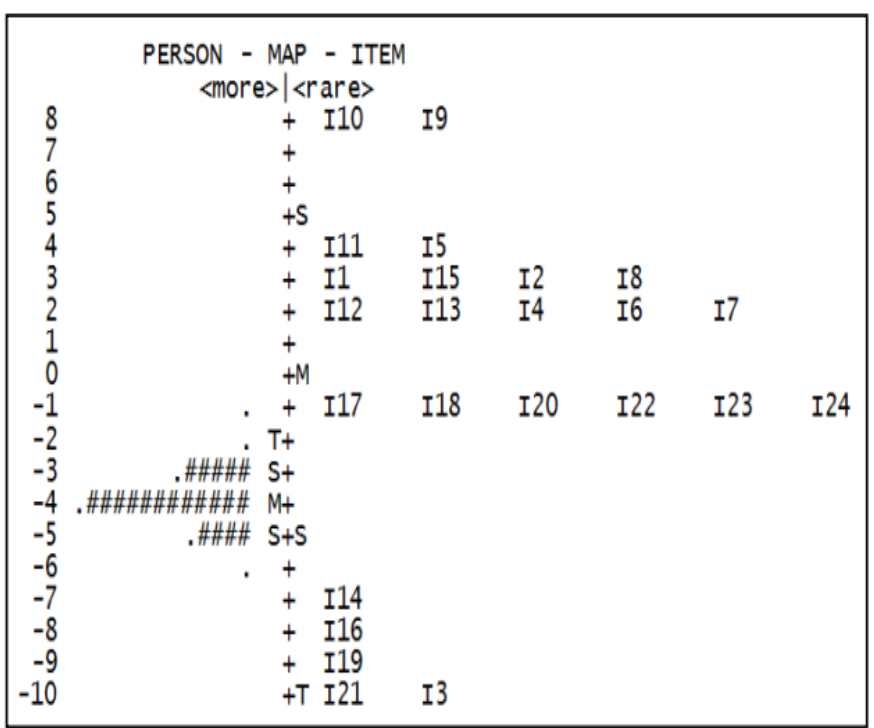

Fig. 1. Food Security Instrument Information Item Diagram.

Based on the analysis of food security instruments developed by consisting of 24 questions using the Rasch Model approach, the item reliability was 0,99 . This showed that the reliability coefficient of the food security instrument has exceeded the minimum criteria of $0,99>0,75$. Thus it can be said that the food security instrument was feasible to use. 


\section{A. Milkfish Productivity}

Based on the data which were collected from 215 respondents, information was obtained that as much as $93,49 \%$ of respondents stated that if the milkfish consumed by them were produced in the Serang City which supported the results that as many as $53,02 \%$ respondents stated that milkfish productivity in the Serang City was in the very high category. With these results as many as $87,91 \%$ respondents stated that they did not experience difficulties in reaching the location of the purchase of milkfish.

Subsequent results obtained that all respondents stated that milkfish productivity in Serang City had an effect on food security in Serang City. Likewise, milkfish stability will also affect food security in Serang City, as stated by all research respondents. With these results also as much as $50,70 \%$ of respondents stated that the stability of milkfish is very important in maintaining food security in the Serang City.

\section{B. Milkfish Availibility}

Based on the research data were collected from 215 respondents, information was obtained that as much as 93,95\% of respondents stated that the Serang City had sufficient milk supply for now. Likewise with the supply of milkfish in the Serang City during the past year by $74,42 \%$ respondents declared sufficient.

Even so, the supply of milkfish in the Serang City was stated to be sufficient for now, it turns out that $97,21 \%$ respondents think that one day the city of Serang will run out of milk supply. It was shown by $96,74 \%$ which states that the Serang City has experienced a shortage of milkfish which was caused by the death of the milkfish farming business as the most dominant factor, followed by the milkfish products of the Serang City entrepreneurs sold out of the Serang City, the selling price of milkfish too low, and crop failure experienced by milkfish entrepreneurs.

Of course these results lead to the overall respondents stated that the availability of milkfish can affect food security in Serang City where $59,07 \%$ respondents stated that the availability of milkfish in Serang City has an important role on food security in Serang City.

\section{Adequacy of Consumption}

Based on the research data which were collected from 215 respondents, information was obtained that as many as $91,16 \%$ respondents were loyal consumers of milkfish where they consumed milkfish more than three times during the week. It was because the price of milkfish was relatively low as stated by $93,02 \%$ respondents. Even so it turns out that information was obtained if as many as $74,42 \%$ respondents said that they had experienced difficulty finding milkfish in the market when they wanted to buy. With these results, it was very visible if the people of Serang City in general $(91,16 \%)$ experience fear if in the next year the City of Serang experiences a shortage of milkfish.

\section{Milkfish Shortage Solution}

As the results stated in the previous section, from 215 respondents obtained information that in general they experience fear if during the next year Serang City experiences a shortage of milkfish. As many as $95,35 \%$ of respondents stated that the milkfish supply in Serang City was purely from milkfish entrepreneurs in the Serang City area. In addition, as much as $94,88 \%$ of the respondents also stated that the supply of milkfish in Serang City came from milkfish entrepreneurs in the Regencies/Cities around of Serang City, and as many as $91,16 \%$ of respondents stated that the milk supply in Serang City came from milkfish entrepreneurs outside the Banten.

Due to the importance of stability and availability of milkfish in Serang City's food security, all respondents expect the government to have to think of a solution if one day there was a shortage of milkfish in Serang City. This can be done through increasing the number of milkfish entrepreneurs in Serang City or increasing the skills of milkfish entrepreneurs in Serang City.

\section{CONCLUSION}

Based on the research results obtained, the conclusion obtained through this research was the Serang City food security instrument which has been developed using the Rasch Model approach consisting of 24 statements with milkfish production supply indicators, consumption adequacy, and milkfish shortage solutions with a reliability coefficient of 0,99 . While the stability and availability of milkfish has a very significant effect on food security in Serang City.

\section{REFERENCES}

[1] Rachmaningsih, T \& Priyarsono, D.S. (2012). Ketahanan Pangan di Kawasan Timur Indonesia. Jurnal Ekonomi dan Pembangunan Indonesia, 13(1): 1-18

[2] Naga, Dali Santun. 2013. Teori Skor pada Pengukuran Mental Edisi Kedua. Jakarta: PT. Nagarani Citrayasa.

[3] Dewan Ketahanan Pangan. (2015). Peta Ketahanan dan Kerentanan Pangan Indonesia Tahun 2015. Retrieved from http://documents.wfp.org/stellent/groups/public/ documents/ena/wfp276267.pdf.

[4] Wisner, B., et.al. (2003). At Risk: Natural Hazards, People's Vulnerability, and Disasters. London, UK and New York, USA: Routledge. doi:10.4324/9780203428764.

[5] Davies, A. (2009). Food Security Initiatives In Nigeria: Prospects and Challenges. Journal of Sustainable Development in Africa, 11(1): 186-202.

[6] Gross, R., et.al. (2000). The Four Dimensions of Food and Nutrition Security: Definitions and Concepts. http://www.fao.org/elearning/course/FA/en/pdf/P01_RG_Concept.pdf (Accessed September 3, 2019).

[7] Prabowo, R. (2010). Kebijakan Pemerintah dalam Mewujudkan Ketahanan Pangan di Indonesia. Jurnal Ilmu-Ilmu Pertanian, 6(2): 6273.

[8] Boone, W. J., Staver, R. J., \& Yale, S. M. (2014). Rasch Analysis in the Human Sciences. London: Springer. 